ORIGINAL ARTICLE

\title{
In Vitro Assessment of Antimicrobial Potential of Ethanolic and Aqueous Extract of Phlomis Umbrosa Against Some Highly Resistant Pathogens
}

\author{
Yousra Shafiq ${ }^{1}$, Muhammad Arif Asghar ${ }^{1}$, Huma Ali ${ }^{1}$, Saima Abedien ${ }^{1}$, Ahad Abdul Rehman ${ }^{2}$, and \\ Humaira Anser ${ }^{2}$
}

\begin{abstract}
Objective: To find out the antibacterial potential of ethanolic and aqueous roots extract of Phlomis umbrosa $L$. against both Gram positive and Gram negative isolates

Methodology: Disk diffusion method according to Clinical Laboratory and Standards Institute (CLSI) standard was used to examine the in vitro antibacterial activity of $P$. umbrosa extract while minimum inhibitory concentration (MIC) and minimum bactericidal concentration (MBC) were determined using broth dilution technique. Miles and Misra technique was also utilized to count the number of colonies CFU/mL of bacteria at different concentrations of extract.

Results: All the studied strains showed a diverse range of vulnerability against both ethanolic and aqueous plant extract. Among all tested isolates, ethanolic extract of $P$. umbrosa showed highly significant activity against Gram positive isolates i.e. S. aureus $(20.1 \mathrm{~mm})$ and B. subtilis $(22.9 \mathrm{~mm})$ with least MIC $(12.5 \mathrm{mg} / \mathrm{mL})$ and $\mathrm{MBC}(12.5 \mathrm{mg} / \mathrm{mL})$ as compared to Gram negative isolates. A progressive decline in bacterial colonies $(\mathrm{CFU} / \mathrm{mL})$ was observed in Miles and Misra technique. One way ANOVA followed by postHoc Tukey test showed the significant differences in antimicrobial activities of plant extract with two tested antibiotics i.e. Amoxicillin and Erythromycin $(10 \mu \mathrm{g} / \mathrm{disc})$ as positive control at p-value of 0.05 . The antimicrobial activity of this plant exhibit may be due to the presence of such chemical constituents namely monoterpenoids and sesquiterpenoids compounds.

Conclusion: It is concluded that roots ethanolic extract of $P$. umbrosa has a promising antibacterial potential so it can also be used as an alternative medicine to treat different infections for reducing bacterial resistance and side effects associated with antibiotics.
\end{abstract}

Key words: Phlomis umbrosa; amoxicillin; erythromycin; antimicrobial activity; Miles and Misra method

How to cite this article: Shafiq Y, Asghar MA, Ali H, Abedien S, Rehman AA, Anser H. In vitro assessment of antimicrobial potential of ethanolic and aqueous extract of phlomis umbrosa against some highly resistant pathogens.

Ann Jinnah Sindh Med Uni 2020; 6(1):3-9

DOI:https://doi.org/10.46663/ajsmu.v6i1.3-9

\section{INTRODUCTION}

For centuries, the use of medicinal plants as an essential source of medicinal agents for maintaining good health is well known and a number of novel compounds have been isolated from such plants ${ }^{1}$. Around $80 \%$ of population relies on traditional medicines primarily from herbal origins. Secondary metabolites as tannins, flavonoids, terpenoids, and alkaloids extracted from plants with high structure diversity possess strong antimicrobial significance ${ }^{2}$.

Department of Pharmaceutics 1 / Department of Pharmacology ${ }^{2}$, Institute of Pharmacutical Sciences, Jinnah Sindh Medical University, Karachi, Pakistan

Correspondence: Muhammad Arif Asghar,, Department of Pharmaceutics, Institute of Pharmacutical Sciences, Jinnah Sindh Medical University, Karachi, Pakistan

Email: arif.asghar@jsmu.edu.pk
Moreover, rising credence is being given to the extraction and augmentation of distinct medicines from plants in modern culture ${ }^{3}$. Studies show that large populations heavily rely on medicinal plants to fulfill their primary health care needs ${ }^{4}$.

Antimicrobial resistance (AMR) against pathogenic bacteria or multidrug resistant bacteria (MDR or superbugs), is a serious global threat for humans, animals, environmental health, and one of the major causes for endangering the worth of antibiotics. Reduction in financial inducement, inadequacy of newer drugs, over the counter availability, poor hygiene and sanitation, and misuse of antibiotics are attributable to the crisis of antimicrobial resistance. Comprehensive efforts are needed to minimize the pace of resistance by studying emergent microorganisms, resistance mechanisms, and antimicrobial agents ${ }^{5}$. 
This dilemma features the immediate demand for advance strategies and latest classes of antibiotics. In developing countries, plants are widely used as a source of medicine where traditional medicine plays a major role in primary healthcare. About $80 \%$ of individuals from these countries still use plants as remedies for many diseases, using their own personal recipes which have been passed down through generations. Clinical plant utilization provides a steady inspiration of bioactive antimicrobial agents with less toxicity, broad microbial coverage and good pharmacokinetics without chemical modification ${ }^{6,7}$.

The genus Phlomis belonging to family Lamiaceae is a perennial herb. More than 100 species are reported from this genus widely distributed throughout Asia, Europe and Africa. Number of species are well known for their aromatic and medicinal function. Many species of this genus have usage for medicinal and aromatic purposes. Folk uses of different species of this plant include as stimulant, carminative, tonic, appetizer, antidiuretic, and in herbal tea. A number of biological activities are reported such as antimicrobial, antiulcerogenic, immunosuppressive and free radical scavenging, and anti-inflammatory ${ }^{8,9}$.

Previously, several studies reported on screening of antimicrobial activities of several medicinal and traditional plants ${ }^{10-12}$. The antimicrobial activity of essential oil of flowers extract of Phlomis umbrosa was also evaluated ${ }^{13}$. However, according to the literature survey, no studies have been conducted on screening of antimicrobial potential of root extract of P. umbrosa. Therefore the aim of this study was to evaluate the antimicrobial activity of aqueous and ethanolic roots extract of P. umbrosa in comparison with standard marketed antibiotics.

\section{METHODOLOGY}

Collection of antimicrobial agents and chemicals Dried powder roots extract of Phlomis umbrosa were recieved from a manufacturer and supplier $\mathrm{M} / \mathrm{S}$. HUNAN NUTRAMAX INC. (Changsha, China) with a batch number of PUE-160419 and was identified by a pharmacognosist and meritorious professor of University of Karachi, Pakistan. The standard antibiotics disc such as erythromycin and amoxicillin were purchased from distributor Musaji Adam and Sons (Karachi, Pakistan). Methanol was purchased from Sigma-Aldrich (St. Louis, USA). DMSO was procured from Merck (Darmstadt, Germany), nutrient agar and Mueller Hinton broth (MHB) were collected from Oxoid LTD (Hemisphere, England). Both antibiotics discs were of $10 \mu \mathrm{g}$.
Collection of different clinical and standard ATCC strains

Gram positive and Gram negative highly resistant clinical strains including Bacillus subtilis (MT 0250), Staphylococcus aureus (MT 0484), Streptococcus pyogenes (MT 0258), Salmonella enterica (MT 0691) were obtained from pathological laboratories of Dr. Essa's Laboratory and Kutiyana Memon Hospital in Karachi, Pakistan. ATCC standard cultures strains used in this study were Bacillus subtilis (ATCC 04262), Staphylococcus aureus (ATCC 08854), Streptococcus pyogenes (ATCC 10258), and Salmonella enterica (ATCC 10691). The received bacterial strains from different laboratories were identified by pathologists based on their cultural, morphological, and biochemical reactions.

\section{Antibacterial activity}

Inoculation of bacterial strain: Antibacterial activity against collected isolates was performed using well reputed disc diffusion method which was first reported in 1940. The Clinical Laboratory and Standards Institute (CLSI) have approved standards for testing of different clinical and highly resistant pathological strains ${ }^{14}$. Two different antibiotics (Amoxicillin $10 \mu \mathrm{g}$ and Erythromycin $10 \mu \mathrm{g} / \mathrm{disc}$ ) as positive control and Phlomis umbrosa ethanolic and aqueous extract disc (6 $\mathrm{mm}$ in diameter) were used to evaluate their antibacterial activity. The discs of plant extract were prepared using concentrations of $(20 \mathrm{mg} / \mathrm{mL}, 30$ $\mathrm{mg} / \mathrm{mL}, 40 \mathrm{mg} / \mathrm{mL}$ and $50 \mathrm{mg} / \mathrm{mL}$ ) dried powder of P. umbrosa obtained by both aqueous and alcoholic solvents. Whereas, Dimethyl sulfoxide (DMSO) was used as negative control in whole study because, it is considered as a non-toxic solvent ${ }^{15}$. These prepared discs were placed on the pre-inoculated Mueller Hinton Agar (MHA) plates with different collected bacterial cultures and were placed in incubator for $24 \mathrm{~h}$ at $37^{\circ} \mathrm{C}$.

Determination of minimum inhibitory concentration (MIC) and minimum bactericidal concentration (MBC): The concentration of extract at which the growth of clinical isolates was inhibited is refered to as minimum inhibitory concentration (MIC) while the concentration used for complete killing of clinical isolate is known as minimum bactericidal concentration (MBC). The MIC and MBC of ethanolic and aqueous root extract of $P$. umbrosa were determined using broth dilution method ${ }^{10}$. As much as $100 \mu \mathrm{L}$ crude root extract of plant was taken to prepare $50 \mathrm{mg} / \mathrm{mL}$ concentration, then further dilution was made using serial dilution method up to $0.5 \mathrm{mg} / \mathrm{mL}$. Tween 20 was used to solubilize the different concentrations of plant extract in nutrient broth. Each bacterial strain was adjusted to the concentration of $1 \times 10^{8} \mathrm{cfu} / \mathrm{mL}$ in 
respective media. The plates of different bacterial strains were incubated at $37^{\circ} \mathrm{C}$ for $24 \mathrm{~h}$. The growth of bacterial strains was examined by the turbidity found in their respective test tubes. The prepared broth culture was incubated at $37^{\circ} \mathrm{C}$ for $24 \mathrm{~h}$ in Tyramide Signal Amplification (TSA) system.

Miles and Misra method: The technique of Miles and Misra was used to examine the antibacterial potential of ethanolic and aqueous root extract of $P$. umbrosa at different concentrations by counting the number of colonies forming units (CFU) of bacteria after exposure to extract ${ }^{16}$. The test isolates suspension was prepared in $\mathrm{pH} 7 \mathrm{PBS}$ buffer and the inoculums of tested organisms defined at $1.5 \times 10^{8}$ cells $/ \mathrm{ml}$ using the 0.5 McFarland index.

\section{Statistical analysis}

All the above defined experiments were performed in triplicates. The obtained results of all experiments were presented as mean \pm standard deviation (SD). Statistical software (SPSS version 23) was used to analyze the obtained data by applying one way ANOVA with Tukey's post Hoc Test at minimal level of significance of $p<0.05$. Furthermore, Pearson correlation was also applied to evaluate the relationship between the concentrations of plant extract with their antimicrobial effects.

\section{RESULTS}

The extract of Phlomis umbrosa roots with ethanol and also in water was light brown in colour and exhibited great antibacterial activity against some highly resistant clinical pathogens including $B$. subtilis, $S$. aureus, S. pyogenes and S. enterica. The obtained antibacterial activities of ethanolic and aqueous extract of plant are dose dependent and found within ranges of $(5.9 \pm 1.074 \mathrm{~mm}$ to $22.6 \pm 1.195 \mathrm{~mm})$ in ethanolic and $(4.0 \pm 0.821 \mathrm{~mm}$ to $17.9 \pm 0.995 \mathrm{~mm})$ in aqueous extract at different concentration as presented in Table 1 and 2 respectively. Among all the tested clinical isolates, Gram positive isolates i.e. S. aureus and $B$. subtilis were highly susceptible to the ethanolic plant extract at $50 \mathrm{mg} / \mathrm{mL}$ i.e. $25.6 \pm 2.009$ and $24.8 \pm 1.371$ respectively. However, the obtained zones of inhibitions from plant extract, primarily ethanolic extract, were much greater and significant than two tested antibiotics. The susceptibility of ethanolic and aqueous extract of plant also tested antibiotics against some ATCC cultures presented in Table 3 and 4. The obtained values of ZIs were significantly different at different concentrations of ethanolic plant extract against clinical isolates i.e. $B$. subtilis $(P=0.016) ; S$. aureus $(P=0.021) ; S$. pyogenes $(P=0.027)$ and $S$. enterica $(P=0.015)$. Moreover, highly significant differences $(P>0.005)$ were found in ZIs of amoxicillin against $B$. subtilis and $S$. enterica while significant differences $(P>0.05)$ were found in antibiotics against tested isolates compared to extract at $30 \mathrm{mg} / \mathrm{mL}$ concentration. The values of MIC and MBC of ethanolic root extract of $P$. umbrosa indicated the positive results in screening test of different clinical highly resistant microbes (Table 5). The lowest and same MIC and MBC values were observed against $B$. subtilis i.e. $12.5 \mathrm{mg} / \mathrm{mL}$ while the highest were against $S$. enterica as $20.0 \mathrm{mg} / \mathrm{mL}$. The Miles and Misra test showed a gradual decrease in log of CFU/mL of bacteria with increasing concentration of both aqueous and ethanolic root extract of $P$. umbrosa as indicated in Figure 1. Among all tested organisms, $\log$ of CFU/mL of $S$. aureus and B. subtilis were decrease up to 3.7 and 3.9 respectively in ethanolic extract.

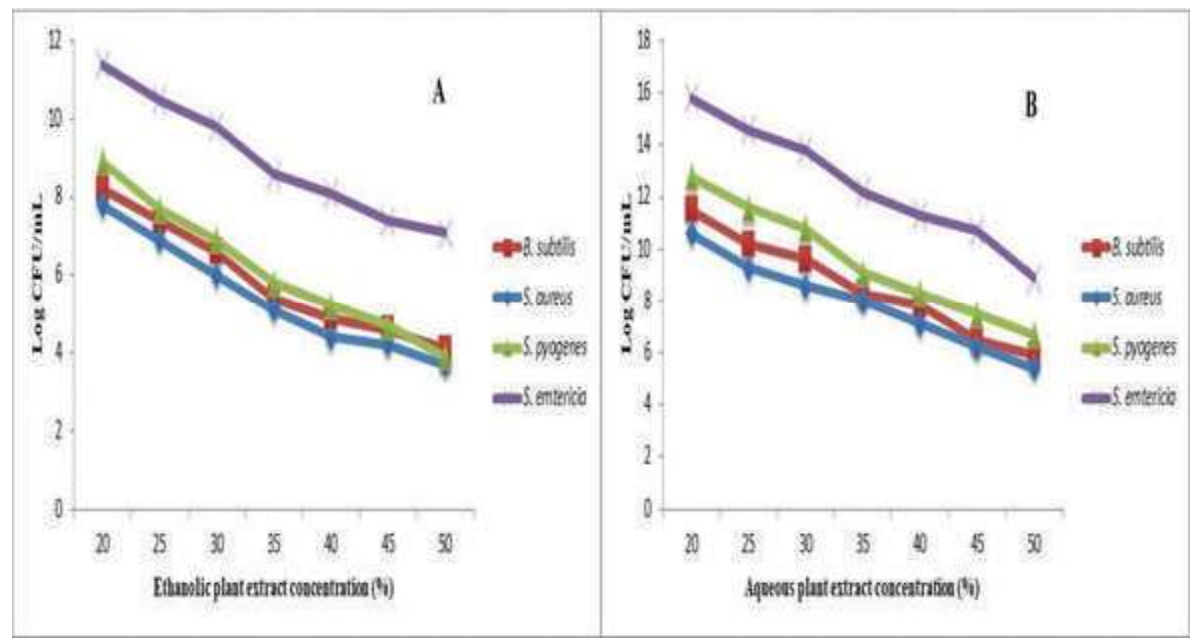

Figure 1: (A) Log of CFU/ml at different concentrations of ethanolic extract (B) Log of $\mathrm{CFU} / \mathrm{ml}$ at different concentrations of aqueous extract 
Table 1: Antibacterial Activity of Ethanolic Plant Extract and Different Antibiotics Against Clinical Isolates

\begin{tabular}{|c|c|c|c|c|c|c|c|c|}
\hline \multirow{3}{*}{$\begin{array}{l}\text { Clinical } \\
\text { isolates }\end{array}$} & \multirow{2}{*}{\multicolumn{6}{|c|}{$\begin{array}{l}\text { Zone of mhibitions in mm } \\
\text { Plant extract(E thanolic) }\end{array}$}} & \multicolumn{2}{|c|}{ Standard drugs } \\
\hline & & & & & & & Amoxicillin & Erythromy̨cin \\
\hline & $20 \mathrm{mg} / \mathrm{mL}$ & $30 \mathrm{mg} / \mathrm{mL}$ & $40 \mathrm{mg} / \mathrm{mL}$ & $50 \mathrm{mg} / \mathrm{mL}$ & $\begin{array}{c}\text { Pearson } \\
\text { correlation }\end{array}$ & $\begin{array}{c}\text { P. } \\
\text { ralue }\end{array}$ & $10 \mu g d d i s c s$ & $10 \mu g d$ discs \\
\hline B. subtilis & $13.8=1.326$ & $15.5=1.461$ & $18.1=0.513$ & $20.1=1.254$ & 0.998 & 0.016 & $9.1=1.224 * *$ & $12.1=1.724^{*}$ \\
\hline S. aurreus & $14.5=0.862$ & $17.0=0.472$ & $21.7=1.316$ & $22.9=1.614$ & 0.985 & 0.021 & $12.6=1.375^{*}$ & $11.5=1.215^{*}$ \\
\hline $\begin{array}{c}\text { S. } \\
\text { pyogenes }\end{array}$ & $10.8=1.246$ & $14.2=1.725$ & $17.6=1.258$ & $20.7=1.290$ & 0.994 & 0.027 & $11.6=1.224^{*}$ & $12.0=1.552^{*}$ \\
\hline S. enterica & $5.9=1.514$ & $8.5=0.914$ & $12.6=1.413$ & $15.7=1.309$ & 0.985 & 0.015 & $7.9=1.256$ ** & $11.6=0.646^{*}$ \\
\hline
\end{tabular}

$\mathrm{n}=10$, Average values $\pm \mathrm{SD}$

$* \mathrm{p}=0.05$ significant as compared to control

$* * \mathrm{p}=0.005$ highly significant as compared to plant extract at concentrations of $50 \mathrm{mg} / \mathrm{mL}$

Table 2: Antibacterial Activitv of Aaueous Plant Extract and Different Antibiotics Against Clinical Isolates

\begin{tabular}{|c|c|c|c|c|c|c|c|c|}
\hline \multirow{3}{*}{$\begin{array}{l}\text { Clinical } \\
\text { isolates }\end{array}$} & \multicolumn{8}{|c|}{ Zone of inhbitions in mm } \\
\hline & \multicolumn{6}{|c|}{ Plant extract(Aqueous) } & \multirow{2}{*}{$\begin{array}{l}\text { Amoxicillin } \\
10 \mu g d \text { discs }\end{array}$} & \multirow{2}{*}{$\begin{array}{l}\text { Enỵthrouycin } \\
10 \text { ॥g/disss }\end{array}$} \\
\hline & $20 \mathrm{mg} / \mathrm{mL}$ & $30 \mathrm{mg} / \mathrm{mL}$ & $40 \mathrm{mg} / \mathrm{mL}$ & $50 \mathrm{mggmL}$ & $\begin{array}{c}\text { Pearson } \\
\text { correation }\end{array}$ & $\begin{array}{c}\text { P. } \\
\text { ralue }\end{array}$ & & \\
\hline B. subthis & $10.0=1.248$ & $12.2 \pm 1.215$ & $14.2 \pm 1.214$ & $15.6=0.825$ & 0.992 & 0.024 & $9.1=0.813^{*}$ & $12.1=1.226$ \\
\hline S. all'als & $9.4=0.925$ & $12.6 \pm 1.425$ & $15.0=1.242$ & $17.9 \pm 0.635$ & 0.993 & 0.014 & $12.6=1.074$ & $11.5=0.673^{*}$ \\
\hline S. piogentes & $7.2 \pm 0.725$ & $8.7=1.346$ & $11.6 \pm 1.220$ & $13.0=0.971$ & 0.987 & 0.021 & $11.6 \pm 1.577$ & $12.0=0.804$ \\
\hline S. enterica & $4.0=0.901$ & $5.9=1.250$ & $7.3 \pm 1.457$ & $9.1=0.729$ & 0.994 & 0.047 & $7.9=0.703$ & $11.6=0.750^{*}$ \\
\hline
\end{tabular}

$\mathrm{n}=10$, Average values \pm S.D

$* p=0.05$ significant as compared to control

$* * \mathrm{p}=0.005$ highly significant as compared to plant extract at concentrations of $50 \mathrm{mg} / \mathrm{mL}$ 
Assessment of phlomis umbrosa vs highly resistant pathogens

Table 3: Antibacterial Activity of Ethanolic Plant Extract and Different Antibiotics Against Standard ATCC Strains

\begin{tabular}{|c|c|c|c|c|c|c|c|c|}
\hline \multirow{3}{*}{ Climical isolates } & \multicolumn{8}{|c|}{ Zone of inlibitions in mm } \\
\hline & \multicolumn{6}{|c|}{ Phat extract (I thanolic) } & Amoxicillim & Irythromscin \\
\hline & $20 \mathrm{mg} \mathrm{mL}$ & $30 \mathrm{mg} / \mathrm{mL}$ & $40 \mathrm{mg} / \mathrm{mL}$ & $30 \mathrm{mgmL}$ & $\begin{array}{c}\text { Pearson } \\
\text { correlation }\end{array}$ & $\begin{array}{c}\text { P. } \\
\text { value }\end{array}$ & $10 \mu \mathrm{g} / \mathrm{dics}$ & 10 ug dises \\
\hline $\begin{array}{c}\text { B. subotlis } \\
\text { (AICC 04262) }\end{array}$ & $163=1.451$ & $19.3=1.126$ & $21.6=1.341$ & $24.8=1.157$ & 0.996 & 0.014 & $16.8=0.742^{*}$ & $20.4=1.265$ \\
\hline $\begin{array}{c}\text { S. aureus } \\
\text { (AICC 08854) }\end{array}$ & $182=1.625$ & $20.2 \pm 1.134$ & $22.4=1.327$ & $25.6=1.709$ & 0.994 & 0.021 & $19.4=0.912^{*}$ & $22.3=1.524$ \\
\hline $\begin{array}{l}\text { S. pyogenes } \\
\text { (ATCC10258) }\end{array}$ & $132=0.996$ & $16.3=1.615$ & $19.7=1.1 .84$ & $23.4=1.525$ & 0.991 & 0.018 & $17.3=0.742^{*}$ & $22.0=0.814$ \\
\hline $\begin{array}{c}\text { S.enterica } \\
\text { (ATCC 10691) }\end{array}$ & $8.4=1.604$ & $11.5=1.260$ & $14.0=1.610$ & $18.2=0.723$ & 0.988 & 0.009 & $14.7=1.459$ & $15.3 \pm 1.230$ \\
\hline
\end{tabular}

$\mathrm{n}=10$, Average values \pm S.D

$* \mathrm{p}=0.05$ significant as compared to control

$* * \mathrm{p}=0.005$ highly significant as compared to plant extract at concentrations of $50 \mathrm{mg} / \mathrm{mL}$

Table 4: Antibacterial Activity of Aqueous Plant Extract and Different Antibiotics Against Standard ATCC Strains

\begin{tabular}{|c|c|c|c|c|c|c|c|c|}
\hline \multirow{3}{*}{ Climical isolates } & \multicolumn{8}{|c|}{ Zone of inhibitions in mm } \\
\hline & \multicolumn{6}{|c|}{ Plant extract(Aqueous) } & \multirow{2}{*}{$\frac{\text { Amoxicillin }}{10 \mu g \text { discs }}$} & \multirow{2}{*}{$\begin{array}{l}\text { Enthromycil } \\
10 \text { pg/discs }\end{array}$} \\
\hline & $20 \mathrm{mg} / \mathrm{mL}$ & $30 \mathrm{mg} / \mathrm{mL}$ & $40 \mathrm{mg} / \mathrm{mL}$ & $50 \mathrm{mg} / \mathrm{mL}$ & $\begin{array}{l}\text { Pearson } \\
\text { correlation }\end{array}$ & P-ralue & & \\
\hline $\begin{array}{c}\text { B. subtilis } \\
\text { (ATCCO4262) }\end{array}$ & $12.3=0.743$ & $14.1=1.424$ & $16.8=1.42$ & $18.7=1.273$ & 0995 & 0.012 & $16.8=0.736$ & $20.4=1.363^{*}$ \\
\hline $\begin{array}{c}\text { Salvelis } \\
\text { (ATCC 08854) }\end{array}$ & $10.5=0.642$ & $13.8=0.757$ & $16.8=1.635$ & $18.0=1.356$ & 0988 & 0.026 & $19.4=1324$ & $22.3=1.642^{*}$ \\
\hline $\begin{array}{l}\text { S. pjogenes } \\
\text { (ATCC 102:58) }\end{array}$ & $8.6=0.853$ & $109=0.681$ & $13.0=1.635$ & $16.7=1.635$ & 0986 & 0.024 & $17.3=1206$ & $22.0=0.752^{8}$ \\
\hline $\begin{array}{c}\text { Sentenica } \\
\text { (ATCC 1069) }\end{array}$ & $6.2=0.692$ & $8.4=1.624$ & $9.9=1.344$ & $12.3=0.843$ & 0992 & 0.031 & $14.7=1526$ & $15.3=1.532$ \\
\hline
\end{tabular}

$\mathrm{n}=10$, Average values \pm S.D

$* \mathrm{p}=0.05$ significant as compared to control

$* * \mathrm{p}=0.005$ highly significant as compared to plant extract at concentrations of $50 \mathrm{mg} / \mathrm{mL}$

Table 5: MIC and MBC of Ethanolic and Aqueous Extract Against Clinical Isolates

\begin{tabular}{c|c|c|c|c|}
\hline \multirow{2}{*}{ Clinical Isolates } & \multicolumn{2}{|c|}{ Ethanolic Extmact } & \multicolumn{2}{c|}{ Aqueous Extract } \\
\cline { 2 - 5 } & MIC $(\mathrm{mg} / \mathrm{mL})$ & $\mathrm{MBC}(\mathrm{mg} / \mathrm{mL})$ & $\mathrm{MIC}(\mathrm{mg} / \mathrm{mL})$ & $\mathrm{MBC}(\mathrm{mg} / \mathrm{mL})$ \\
\hline B. subtilis & $12.5 \pm 1.381$ & $12.5 \pm 1.513$ & $15.0 \pm 1.424$ & $15.0 \pm 1.753$ \\
\hline S. aureus & $12.5 \pm 1.514$ & $15.0 \pm 1.361$ & $17.5 \pm 1.467$ & $17.5 \pm 1.646$ \\
\hline S. pyogenes & $15.0 \pm 0.724$ & $15.0 \pm 1.525$ & $20.0 \pm 1.624$ & $20.0 \pm 1.632$ \\
\hline S. enterica & $20.0 \pm 0.510$ & $20.0 \pm 1.424$ & $25.0 \pm 0.585$ & $30.0 \pm 0.745$ \\
\hline
\end{tabular}

$\mathrm{n}=10$, Average values \pm S.D 


\section{DISCUSSION}

One of the most pressing issues around the world is anti-microbial resistance. In order to overcome this problem, there is an immediate need of new antimicrobial agents with novel systems of activity. Scientific strategies are being adopted based on continuous planning and processing by researchers to find out new antimicrobial agents with minimum side effects and maximum efficacy. In developing countries, traditional medicines are gaining importance persistently. A number of plant and herb species are available in the market with strong antimicrobial potential $^{17}$.

In the present study, the antibacterial potential of Phlomis umbrosa was determined using ethanolic and aqueous crude root extract at different concentrations (Table 1 and 2). It was observed that with the increase in concentration, sensitivity of organism towards sample also increased. Pearsons correlations was used to show dose dependent effect of plant extract on their antibacterial efficacy. The correlation values of Pearson correlations analysis also indicated the dose dependent antibacterial activities of plant extract in both ethanolic and aqueous medium.

However, ethanolic extract was found to be more effective compared to aqueous extract against Gram positive isolates than Gram negative isolates. Miscibility of ethanol with water is well known because of its low polarity compared to water and active microbial compounds present in plants are mostly saturated and non-polar. Lipophilic compounds are difficult to extract in water, while ethanol and methanol are good choices of solvents in such cases ${ }^{18,19}$. Earlier, Guang-hui et al studied the phytochemical components accounted for $91.53 \%$ of the all peak area in P. umbrosa flowers extract. They reported the antimicrobial activity of this plant occuring due to the presence of such chemical constituents as monoterpenoids and sesquiterpenoids compounds, the major components were toluene, phthalic acid, diisobutyl ester, á-linalool, diphenylamine, and 1-octen-3-ol ${ }^{13}$.

A number of antibiotics reported resistance against these collected pathogenic strains. Literature illustrates that Penicillin G, Gentamycin, lincosamide and tetracycline show resistance pattern against these organisms. In case of both aqueous and ethanolic extracts, maximum activity was found against Staphylococcus aureus followed by Bacillus subtilis with zone of inhibition (22.9 \pm 1.195$)$ and $(20.1 \pm$ $0.755)$ at concentration of $50 \mathrm{mg} / \mathrm{mL}$ respectively.
These findings are in line with the study performed by Hui et al., in 2008 on antimicrobial activity ${ }^{20}$. Moreover, Morteza-Semnani et al., in 2006, reported the antibacterial activity of Phlomis species against some highly resistant pathogen including $E$. coli, $K$. pneumonia, S. aureus, S. sanguis, and P. aeruginosa ${ }^{21}$. However, limited data is available on antimicrobial studies of this plant in Pakistan, but according to our study, this plant would be a promising future candidate against microbes.

S. enterica was least sensitive isolate against test sample except at $50 \mathrm{mg} / \mathrm{mL}$ with zone of inhibition $(15.7 \pm$ 1.419). Erythromycin (10 $\mu \mathrm{g} /$ discs) was more effective compared to amoxicillin ( $10 \mu \mathrm{g} / \mathrm{discs})$ used as positive control. Results were also noticed against ATCC cultures and it was observed that standard cultures were more sensitive towards plant extract in comparison to clinical isolates. Mounting graph of resistance among clinical isolates may be contributed to by a number of reasons playing their role in lack of antimicrobial potential. Minimum Inhibitory Concentration (MIC) and Minimum Bactericidal Concentration (MBC) were also determined (Table 5). Least value of MIC was analyzed against $S$. aureus $(12.5 \pm 1.011 \mathrm{mg} / \mathrm{ml})$ with MBC value of $15.0 \pm 1.254 \mathrm{mg} / \mathrm{mL}$. ANOVA followed by post Tukey showed significant differences in antimicrobial activities of plant extract with two tested antibiotics.

The results of Miles and Misra technique also showed the inhibitory effect of ethanolic as well as aqueous extract of $P$. umbrosa against both tested clinical and standard ATCC cultures by lowering down the log of $\mathrm{CFU} / \mathrm{ml}$ at increasing concentrations of plant extract. Inhibitory effect of this plant even at low doses also supports its use in folk medicine for not only the treatment of infectious diseases but also for other ailments. Therefore, it appears to be promising for treatment of bacterial infections. Activity directed bioassay along with extensive activity of bioactive compounds is required for further investigation of compounds actually responsible for antimicrobial potential.

\section{CONCLUSION}

Study showed that crude root extract of $P$. umbrosa have potent antimicrobial potential and produce both bacteriostatic and bactericidal effects. The low values of MIC and MBC reflected the antibacterial potency of this studied plant. It is recommended that systematic and focused researches are required to get new chemical, biological and pharmacological findings. 
Authors' contributions: Dr Yousra Shafiq designed the initial study, searched related literature, collected data and conducted the study. Dr. Muhammad Arif Asghar designed the initial draft of manuscript, reviewed and made corrections. Dr Huma Ali worked on literature search, review and finalized results and discussion. Dr Saima Abedien reviewed the literature, and contributed to the discussion. Dr Ahad Abdul Rehman reviewed the study outcomes and conclusion. All authors contributed to the final manuscript.

Conflict of interest: No conflict of interest associated with this work

\section{References}

1. Owolabi OJ, Omogbai EK, Obasuyi O. Antifungal and antibacterial activities of the ethanolic and aqueous extract of Kigelia africana (Bignoniaceae) stem bark. Afr J Biotechnol 2007;6(14):1677-80.

2. Bouzada ML, Fabri RL, Nogueira M, Konno TU, Duarte GG, Scio E. Antibacterial, cytotoxic and phytochemical screening of some traditional medicinal plants in Brazil. Pharm Biol 2009;47(1):44-52.

3. Cowan MM. Plant products as antimicrobial agents. ClinMicrobiol Rev 1999;12(4):564-82.

4. Nathan C, Cars O. Antibiotic resistance-problems, progress, and prospects. N Eng J Med 2014;371(19): 1761-3.

5. Davies J, Davies D. Origins and evolution of antibiotic resistance. Microbiol Mol Biol Rev 2010;74(3):41733.

6. Adcock H. Pharmageddon: is it too late to tackle growing resistance to anti-infectives? Pharm J 2002;269(7221): 599-600.

7. Rosato A, Vitali C, De Laurentis N, Armenise D, Milillo MA. Antibacterial effect of some essential oils administered alone or in combination with Norfloxacin. Phytomed 2007;14(11):727-32.

8. Zhou Q, Liu Y, Liu X, He J. Studies of the factors linked to the bacteriostatic ability of Lactobacillus in human vagina. Wei Sheng Yan Jiu. 2006;35(3):310-3.

9. Demirci F, Guven K, Demirci B, Dadandi M, Baser K. Antibacterial activity of two Phlomis essential oils against food pathogens. Food Cont. 2008;19(12):115964.

10. Shafiq Y, Naqvi SBS, Rizwani GH, Abbas T, Sharif H, Ali $\mathrm{H}$, et al. Assessment of killing kinetics assay and bactericidal mechanism of crude methanolic bark extract of Casuarina equisetifolia. Pak J Pharm Sci. 2018;31(5 (Supplementary)):2143-8.
11. Mumtaz N, Asghar MA, Naqvi SBS, Asghar MA, Raza ML, Rehman AA. Time kill assay and bactericidal mechanism of action of ethanolic flowers extract of Sphaeranthus indicus. RADS J Pharm Pharm Sci. 2019;7(1):27-33.

12. Dorman HJD, Deans SG. Antimicrobial agents from plants: antibacterial activity of plant volatile oils. J App Mmicrobiol 2000;88(2):308-16.

13. Tian GH, Liu CF, Wei C, Lai PH. Study on component analysis and antimicrobial activity of the essential oil of the flower of Phlomis umbrosa. Chin J Pharm Anal. $2009 ; 3$.

14. CLSI C. Performance standards for antimicrobial susceptibility testing. Clinical and Laboratory Standards Institute (M100eS22). 2012(s22nd Informational Supplement).

15. Quinn B, Gagné F, Blaise C. An investigation into the acute and chronic toxicity of eleven pharmaceuticals (and their solvents) found in wastewater effluent on the cnidarian, Hydra attenuata. Sci Total Environ. 2008;389(2-3):306-314.

16. Khan I, Abbas T, Anjum K, Abbas SQ, Shagufta BI, Shah A, et al. Antimicrobial potential of aqueous extract of Camellia sinensis against representative microbes. Pak J Pharm Sci 2019;32(2):631-6.

17. Munuswamy H, Thirunavukkarasu T, Rajamani S, Elumalai EK, Ernest D. A review on antimicrobial efficacy of some traditional medicinal plants in Tamilnadu. J Acute Dis. 2013;2(2):99-105.

18. Muthaura C, Keriko J, Mutai C, Yenesew A, Gathirwa $\mathrm{J}$, Irungu B, et al. Antiplasmodial potential of traditional antimalarial phytotherapy remedies used by the Kwale community of the Kenyan Coast. J Ethnopharmacol. 2015;170:148-57.

19. Tona L, Ngimbi N, Tsakala M, Mesia K, Cimanga K, Apers S, et al. Antimalarial activity of 20 crude extracts from nine African medicinal plants used in Kinshasa, Congo. J Ethnopharmacol. 1999;68(1-3):193-203.

20. Tian GH, Liu CF, Lai PH. Study on Volatile Components and Antimicrobial Activity of the Essential Oil from the Flower of Polygonum amplexicaule. Lishizhen Med Materia Medica Res.2008;7.

21. Morteza-Semnani K, Azadbakht M, Goodarzi A. The essential oils composition of Phlomis herba-venti L. leaves and ?owers of Iranian origin. Flavour Fragr J. 2004;19(1):29-31. 